Brit. J. prev. soc. Med. (1958), 12, 156-158

\title{
HOSPITAL SIZE AND STAFF SICKNESS RATES
}

\author{
BY \\ A. BARR \\ Oxford Regional Hospital Board
}

It has been shown for various industries that the morale of the staff is closely related to the size of the organization. Thus, for an industrial combine of ninety units, Acton Society Trust (1954) found a clear relationship between size (ranging from 8 to 11,000 employees) and morale measured in terms of sick leave, number of accidents, and length of time taken to recover from an accident. In a similar type of investigation in coalfields, lost time was found to increase with the size of the pit. Moreover, under similar geological conditions, output per man-shift tended to be no higher-and was often appreciably lower-in large pits than in small. Any general improvement in output tended to be more marked in the smaller pits.

A detailed study of the relationship between size and morale in five selected firms confirmed the impression obtained in the general survey (Acton Society Trust, 1957). The connecting link appeared to be "management". As firms grew in size, so the management became more remote and impersonal and, inturn, the worker developed a lack of responsibility towards his job. It was felt that morale could be raised in large organizations by the development of small working units under competent managers.

More recently, Professor Revans, in an address to the Conference on Hospital Authorities and Staff Public Administration (Revans, 1957), quoted figures to show that the accident rate in American hospitals was related to the size of the hospital. The rate, based on 4,680 hospitals in the United States employing over 800,000 (the bulk of whom were nurses), for the year 1953, showed an increase from 2. 6 per million employee-hours exposure in hospitals employing less than ten persons to 13.0 in hospitals employing over one thousand persons.

\section{Material}

An opportunity for examining the association between the size of the hospital and the sickness absence of nurses in the hospitals of the United
Oxford Hospitals and Oxford Regional Hospital Board was presented in the special survey of nurses' absence. This survey covered all sickness and nonsickness absence experienced by all nursing staff during the year ending March 31,1957 . A census of the staff at risk, on lines similar to the national census, was taken half-way through the survey. As a result, a considerable volume of material is available on many different aspects, the details of which will be published later. For present purposes the material is confined to sickness absences among student nurses, because they were the most homogeneous and sensitive group. In particular, the students were roughly of the same age and length of service so that any observed differences would be unlikely to arise in this respect. Further, the hospitals at which the students were employed had to comply with a certain basic minimum standard prescribed by the General Nursing Council, which entails a certain degree of uniformity between the hospitals considered. A possible disadvantage of limiting the comparison to students is that only $\mathbf{5 1}$ of the 103 hospitals surveyed had a nurse-training scheme and are thus included in the analysis. But, this group embraces a considerable range both in size of hospital unit and volume of work performed, so that the disadvantage is relatively unimportant.

\section{RESULTS}

The number of days absent through sickness are given according to the number of students employed at the hospital (Table I), the average number of available beds (Table II), and the turnover of patients per bed per annum (Table III). In each Table the expected number of days has been calculated on the null hypothesis, namely that there is no difference between the sickness absence at the various hospitals. The average length of absence is the observed number of days absent in the particular group of students divided by the total number of students in that group. The proportion of time lost is the total duration of all spells of sickness that occurred partly or wholly within that period divided 
TABLE I

SICKNESS ABSENCE AMONG STUDENT NURSES FOR 12 MONTHS ENDING 31 MARCH, 1957, ANALYSED ACCORDING TO NUMBER OF STUDENT STAFF EMPLOYED AT THE HOSPITAL, NUMBER OF OBSERVED DAYS ABSENT, AND NUMBER OF DAYS ABSENT EXPECTED ON THE NULL HYPOTHESIS, AVERAGE LENGTH OF ABSENCE, AND PROPORTION OF TIME LOST

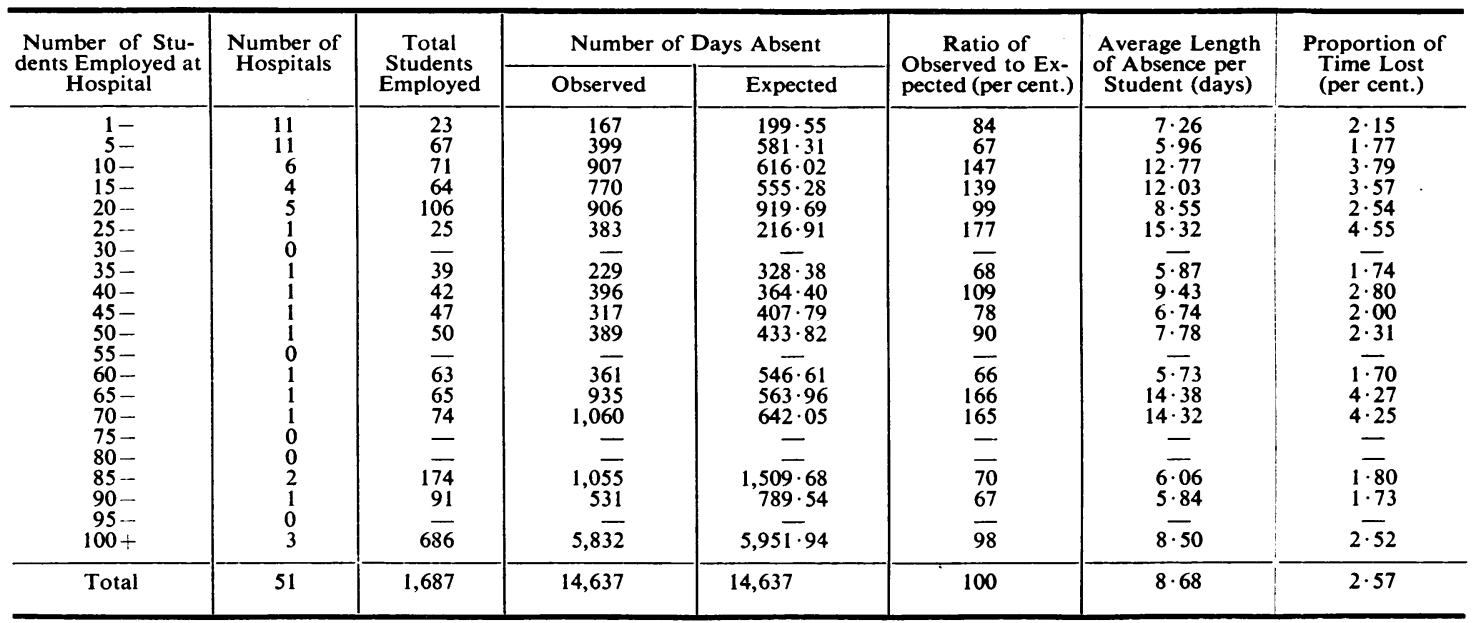

TABLE II

SICKNESS ABSENCE AMONG STUDENT NURSES FOR 12 MONTHS ENDING 31 MARCH, 1957, ANALYSED ACCORDING TO NUMBER OF AVAILABLE BEDS AT THE HOSPITAL, NUMBER OF OBSERVED DAYS ABSENT AND NUMBER OF DAYS ABSENT EXPECTED ON THE NULL HYPOTHESIS, AVERAGE LENGTH OF ABSENCE, AND PROPORTION OF TIME LOST

\begin{tabular}{|c|c|c|c|c|c|c|c|}
\hline \multirow{2}{*}{$\begin{array}{l}\text { Number of } \\
\text { Available Beds }\end{array}$} & \multirow{2}{*}{$\begin{array}{l}\text { Number of } \\
\text { Hospitals }\end{array}$} & \multirow{2}{*}{$\begin{array}{c}\text { Total } \\
\text { Students } \\
\text { Employed }\end{array}$} & \multicolumn{2}{|c|}{ Number of Days Absent } & \multirow{2}{*}{$\begin{array}{l}\quad \text { Ratio of } \\
\text { Observed to Ex- } \\
\text { pected (per cent.) }\end{array}$} & \multirow{2}{*}{$\begin{array}{l}\text { Average Length } \\
\text { of Absence per } \\
\text { Student (days) }\end{array}$} & \multirow{2}{*}{$\begin{array}{l}\text { Proportion of } \\
\text { Time Lost } \\
\text { (per cent.) }\end{array}$} \\
\hline & & & Observed & Expected & & & \\
\hline $\begin{array}{r}1- \\
25- \\
50- \\
75- \\
100- \\
125- \\
150- \\
175- \\
200- \\
225- \\
250- \\
275- \\
300- \\
400- \\
500- \\
750+\end{array}$ & $\begin{array}{l}3 \\
8 \\
4 \\
8 \\
3 \\
3 \\
3 \\
1 \\
3 \\
1 \\
1 \\
3 \\
0 \\
3 \\
2 \\
2 \\
4\end{array}$ & $\begin{array}{r}8 \\
30 \\
44 \\
111 \\
56 \\
49 \\
84 \\
21 \\
35 \\
91 \\
89 \\
220 \\
94 \\
508 \\
247\end{array}$ & $\begin{array}{r}0 \\
91 \\
430 \\
1,404 \\
421 \\
325 \\
1,183 \\
145 \\
287 \\
531 \\
711 \\
1,280 \\
695 \\
4,868 \\
2,266\end{array}$ & $\begin{array}{r}69 \cdot 41 \\
260 \cdot 29 \\
381 \cdot 76 \\
963 \cdot 07 \\
485 \cdot 87 \\
425 \cdot 14 \\
728 \cdot 81 \\
182 \cdot 20 \\
303 \cdot 67 \\
789 \cdot 54 \\
772 \cdot 19 \\
- \\
1,980 \cdot 79 \\
815 \cdot 57 \\
4,407 \cdot 56 \\
2,143 \cdot 05\end{array}$ & $\begin{array}{r}0 \\
35 \\
113 \\
146 \\
87 \\
76 \\
162 \\
80 \\
95 \\
67 \\
92 \\
67 \\
85 \\
110 \\
106\end{array}$ & $\begin{array}{r}0 \\
3 \cdot 03 \\
9 \cdot 77 \\
12 \cdot 65 \\
7 \cdot 52 \\
6 \cdot 63 \\
14 \cdot 08 \\
6 \cdot 90 \\
8 \cdot 20 \\
5 \cdot 84 \\
7 \cdot 99 \\
5 \cdot 8 \\
5 \cdot 81 \\
7 \cdot 39 \\
9 \cdot 58 \\
9 \cdot 17\end{array}$ & $\begin{array}{r}0 \\
0 \cdot 90 \\
2 \cdot 90 \\
3 \cdot 75 \\
2 \cdot 23 \\
1 \cdot 97 \\
4 \cdot 18 \\
2 \cdot 05 \\
2 \cdot 43 \\
1 \cdot 73 \\
2 \cdot 37 \\
1.73 \\
2 \cdot 19 \\
2 \cdot 84 \\
3 \cdot 67\end{array}$ \\
\hline Total & 51 & 1,687 & 14,637 & 14,637 & 100 & $8 \cdot 68$ & $2 \cdot 57$ \\
\hline
\end{tabular}

by the total duration of exposure to risk in the period (General Register Office, 1954). In this instance the period of exposure to risk was assumed to be 337 days (i.e. 365 days less 28 days statutory leave). The average sickness period is related to the proportion of working time lost by the reciprocal of the number of possible working days.

Tables I to III show that there was no apparent association between sickness absence rate and the size of the hospital measured in terms of students employed, or average number of available beds, or turnover per bed. This is confirmed by the productmoment correlation analysis of Table IV (overleaf).

\section{Discussion}

The lack of association between hospital size and rate of staff sickness absence in this analysis of student nurses' records compared with the reasonably close association found in a variety of industrial occupations may be due to a number of factors.

First, since the analysis is based on one year's observations only, the results may be fortuitous. The Acton Society Trust (1957), for instance, found that lost time records varied considerably from year to year.

Secondly, there is a considerable difference between the size of the hospitals in this survey and 
TABLE III

SICKNESS ABSENCE AMONG STUDENT NURSES FOR 12 MONTHS ENDING 31 MARCH, 1957, ANALYSED ACCORDING TO TURNOVER OF PATIENTS PER BED AT THE HOSPITAL, NUMBER OF OBSERVED DAYS ABSENT, AND NUMBER OF DAYS ABSENT EXPECTED ON THE NULL HYPOTHESIS, AVERAGE LENGTH OF ABSENCE, AND PROPORTION OF TIME LOST

\begin{tabular}{|c|c|c|c|c|c|c|c|}
\hline \multirow{2}{*}{$\begin{array}{c}\text { Turnover per Bed } \\
\text { per Annum }\end{array}$} & \multirow{2}{*}{$\begin{array}{l}\text { Number of } \\
\text { Hospitals }\end{array}$} & \multirow{2}{*}{$\begin{array}{l}\text { Total } \\
\text { Students }\end{array}$} & \multicolumn{2}{|c|}{ Number of Days Absent } & \multirow{2}{*}{$\begin{array}{c}\text { Ratio of } \\
\text { Observed to Ex- } \\
\text { pected (per cent.) }\end{array}$} & \multirow{2}{*}{$\begin{array}{l}\text { Average Length } \\
\text { of Absence per } \\
\text { Student (days) }\end{array}$} & \multirow{2}{*}{$\begin{array}{l}\text { Proportion of } \\
\text { Time Lost } \\
\text { (per cent.) }\end{array}$} \\
\hline & & & Observed & Expected & & & \\
\hline $\begin{array}{c}1- \\
2- \\
4- \\
6- \\
8- \\
10- \\
12- \\
14- \\
16- \\
18- \\
20- \\
22- \\
24- \\
26- \\
28- \\
30- \\
32- \\
34-36\end{array}$ & $\begin{array}{l}6 \\
7 \\
6 \\
2 \\
4 \\
1 \\
1 \\
3 \\
1 \\
2 \\
5 \\
2 \\
1 \\
1 \\
4 \\
2 \\
2 \\
1\end{array}$ & $\begin{array}{r}274 \\
51 \\
46 \\
25 \\
134 \\
2 \\
89 \\
73 \\
12 \\
12 \\
124 \\
26 \\
47 \\
1 \\
155 \\
418 \\
183 \\
15\end{array}$ & $\begin{array}{r}2,636 \\
468 \\
382 \\
145 \\
893 \\
32 \\
593 \\
540 \\
282 \\
32 \\
1,464 \\
219 \\
317 \\
0 \\
1,411 \\
3,980 \\
964 \\
279\end{array}$ & $\begin{array}{r}2,377 \cdot 31 \\
442 \cdot 49 \\
399 \cdot 11 \\
216 \cdot 91 \\
1,162 \cdot 62 \\
17 \cdot 35 \\
772 \cdot 19 \\
633 \cdot 37 \\
104 \cdot 12 \\
104 \cdot 12 \\
1,075 \cdot 86 \\
225 \cdot 58 \\
407 \cdot 79 \\
8 \cdot 68 \\
1,344 \cdot 83 \\
3,626 \cdot 69 \\
1,587 \cdot 76 \\
130 \cdot 14\end{array}$ & $\begin{array}{r}111 \\
106 \\
96 \\
67 \\
77 \\
184 \\
77 \\
85 \\
271 \\
31 \\
136 \\
97 \\
78 \\
0 \\
105 \\
110 \\
61 \\
214\end{array}$ & $\begin{array}{r}9 \cdot 62 \\
9 \cdot 18 \\
8 \cdot 30 \\
5 \cdot 80 \\
6 \cdot 66 \\
16 \cdot 00 \\
6 \cdot 66 \\
7 \cdot 40 \\
23 \cdot 50 \\
2 \cdot 67 \\
11 \cdot 81 \\
8 \cdot 42 \\
6 \cdot 74 \\
0 \\
9 \cdot 10 \\
9 \cdot 52 \\
5 \cdot 27 \\
18 \cdot 60\end{array}$ & $\begin{array}{r}2 \cdot 85 \\
2 \cdot 72 \\
2 \cdot 46 \\
1 \cdot 72 \\
1 \cdot 98 \\
4 \cdot 75 \\
1 \cdot 98 \\
2 \cdot 20 \\
6 \cdot 97 \\
0 \cdot 80 \\
3 \cdot 50 \\
2 \cdot 50 \\
2 \cdot 00 \\
2 \cdot 0 \\
2 \cdot 70 \\
1 \cdot 83 \\
5 \cdot 56\end{array}$ \\
\hline Total & 51 & 1,687 & 14,637 & 14,637 & 100 & $8 \cdot 68$ & $2 \cdot 57$ \\
\hline
\end{tabular}

TABLE IV

CORRELATION ( $r$ ) BETWEEN PROPORTION OF WORKING TIME LOST AND CERTAIN INDICES OF HOSPITAL SIZE

\begin{tabular}{|c|c|c|c|c|}
\hline \multicolumn{2}{|c|}{ Variables Correlated } & \multirow{2}{*}{$\begin{array}{c}\begin{array}{c}\text { Co-efficient } \\
\text { of Correla- } \\
\text { tion }(r)\end{array} \\
+0.16\end{array}$} & \multirow{2}{*}{$\frac{t}{1 \cdot 13}$} & \multirow{2}{*}{$\begin{array}{c}P \\
0.3>P>0.2\end{array}$} \\
\hline \multirow{3}{*}{$\begin{array}{l}\text { Working } \\
\text { Time } \\
\text { Lost } \\
\text { (per cent.) } \\
\text { and }\end{array}$} & $\begin{array}{l}\text { (1) Number of } \\
\text { Students } \\
\text { Employed }\end{array}$ & & & \\
\hline & $\begin{array}{l}\text { (2) Average Avail- } \\
\text { able Beds per } \\
\text { Annum }\end{array}$ & $+0 \cdot 10$ & $0 \cdot 70$ & $0.5>P>0.4$ \\
\hline & $\begin{array}{l}\text { (3) Turnover per } \\
\text { Bed per } \\
\text { Annum }\end{array}$ & $-0 \cdot 12$ & 0.85 & $0.4>P>0.3$ \\
\hline
\end{tabular}

that of the industrial firms or American hospitals on which other observations have been based. The largest hospital included in this survey had less than 1,300 beds and the largest group of students employed at any one hospital was 379 . In contrast, the A'cton Society Trust covered firms with up to 10,000 employees in the general survey and firms with from 58 to 3,500 employees in the subsequent detailed study. The accident rates in American hospitals were based upon hospitals in which the number of employees ranged from less than ten to more than a thousand. In both instances, however, the greatest relative increase in the proportion of time lost in industry and in the accident rate in hospitals occurred between the small and the middle-sized units.

Thirdly, the present analysis relates only to student nurses whose conditions of service and age are relatively homogeneous between hospitals, whereas the comparable analysis in industry is concerned with all workers, irrespective of the type of work performed, age, or length of service. A closer parallel to the industrial survey would be provided by the total sickness rates for all hospital staff. This information is not available at present.

The tentative conclusion to be drawn from this survey is that the size of a hospital or the volume of work has no bearing on the sickness absence of student nurses. Other similar surveys for student nurses as well as for other hospital staff are required before any firm conclusions can be reached regarding the effect of the size of the hospital on staff sickness rates.

\section{SUMmaRY}

(1) Sickness absence ratios for student nurses during the year ended March 31, 1957, at 51 hospitals were correlated with the size of the hospital as measured in terms of the number of students employed; the average number of available beds; and the turnover per bed.

(2) There was no evidence to show that the rate of sickness absence was related to the size of the hospital.

\section{REFERENCES}

Acton Society Trust (1954). "Size and Morale: a Preliminary Study of Attendance at Work in Large and Small Units". London.

(1957). "Size and Morale: a Further Study of Attendance at Work in Large and Small Units". London.

General Register Office (1954). "Measurement of Morbidity. A report of the Statistics Sub Committee of the Registrar General's Advisory Committee on Medical Nomenclature and Statistics". H.M.S.O., London.

Revans, R. W. (1957). "Staff Turnover-its Causes and Remedies?" in "Hospital Authorities and Staff Management", p.34. Royal Institute of Public Administration, London. 